Investigaciones Fenomenológicas, vol. Monográfico 7, 2018, 477-498 e-ISSN: $1885-1088$

\title{
TRANSCENDENTAL GROUND OF INTRINSIC WORTH IN RUSSIAN LITERATURE
}

\author{
FONDO TRANSCENDENTAL DEL VALOR INTRÍNSECO EN LA \\ LITERATURA RUSA
}

Algis Mickunas
Ohio University, Ohio / Vytautas Magnus University / Vilnius Technical
University
mickunaa@ohio.edu

\begin{abstract}
The essay is a phenomenological study of Russian literature as a point of critique of two lifeworlds: the traditional Russian Feudalism with its "decadent" aristocracy, and the modern Western Enlightenment with its values, specifically the "subjective" construction of valuations of all environment and human activities. Russian writers, from Turgenev all the way to Gogol found themselves between those two worlds and sought an answer which of them answers the existential question of human selfworth as an "eidetic" criterion of all values and life worlds, given in direct awareness. Self-worth does not belong to the world of categories, but is apparent in active commitments, such as being truthful, honorable, other and self respect -dimensions absent among modern values.
\end{abstract}

Keywords: Value. Self-worth. Enlightenment. Construction. Constitution. Life-world
Resumen: El ensayo es un estudio fenomenológico de la literatura rusa como un punto de crítica de dos mundos: el Feudalismo ruso tradicional con su aristocracia "decadente" y la Ilustración occidental moderna con sus valores -concretamente, la construcción "subjetiva" de evaluaciones de todo tipo de ambiente y actividades humanas. Los escritores rusos, desde Turgenev hasta Gogol, se encontraron entre esos dos mundos y buscaron una respuesta que respondiera a la cuestión existencial de la autoestima humana como un criterio "eidético" de todos los valores y mundos de la vida, dado en conciencia directa. La autoestima no pertenece al mundo de las categorías, sino que se manifiesta en los compromisos activos, tales como ser veraz, ser honorable, respeto propio y ajeno -dimensiones ausentes entre los valores modernos.

Palabras clave: Valor. Autoestima. Ilustración. Construcción. Constitución. Mundo de la vida. 


\section{INTRODUCTION}

Prof. Lester Embree's most recent phenomenological concerns were with culture and its philosophical significance. Given these concerns, the following essay is a supplement to his cultural studies, showing how literatures can be appropriate access to basic human issues in a cultural lifeworld. Such issues appear in Russian literature which might seem to be hardly a matter of professional philosophers, and yet it deals with profound metaphysical, social, economic and moral issues. The term "literature" is, accordingly, not restricted to stories and novels, but to essays on topics ranging from metaphysics through revolution. Given such understanding this essay traces an eidetic invariant in Russian literature that was and is still available, but, as a transcendental intentionality, struggled to be fulfilled in the life worlds of $18^{\text {th }}, 19^{\text {th }}$ and $20^{\text {th }}$ centuries. The struggle was and is between the immediately lived, but not thematized intentionality toward intrinsic self worth, expressed in sacral and secular modes of writing and the world of traditional and Westernizing values. To understand this intentionality it is necessary to make a phenomenological distinction between constitution and construction. Constitutive intentionality opens up or discloses an eidos that either can or cannot be fulfilled in a given life world. The latter is a signitive interconnection of all events and objectivities, including a self interpretation of the subject as being in this life world. It is given as self evident and taken for granted that all events and objectivities in it are realities in their own right. For example, in the West and East it is granted that we live in an economic world, where things, processes and people have economic value. Whether we like it or not, we understand this world as our reality and cannot see any reason to doubt it-despite our complaints that this reality is unfair to some or even should be rearranged differently-and still economically. Even our scientific and technical achievements have the same value. What is crucial is the recognition of "value" as an invariant in this type of life world. Here we also find the separation of value from fact. Facts, for modern Western ontology, have no value. Hence, values are constructed and imposed by us on facts. Such imposition takes on various forms, one of which is the globalization of "Western values" and above all of technocratic rulership by qualified experts. 
The great Russian literatures faced this Westernization and "modernization" and hence were written between two life worlds: one that was maintained as an established tradition, the other as a construct of Scientific and Political Enlightenments of the West. The former, the feudal-aristocratic was deemed to be decadent, corrupt by some, and by others as spiritually superior although in need for revisions, specifically its serfdom. The latter, the West, while partially unknown and alien, was regarded as the bearer of ideas that would transform Russia and bring it into its proper place as a European nation. While numerous texts categorize Russian philosophies in terms of Slavophiles and Westernizers, idealistic and materialistic, nihilistic, theocentric and secular, our task is to disclose the lived awareness that comprises eidetic invariants which are not posited as objects of reflection. Rather, they comprise a tacit awareness in terms of which all judgments are made, whether such judgments are phrased theologically, politically, ethically, socially, or economically. In this sense, the appearance in Russia of Western Enlightenment brought in various systems, from Romanticism through Idealism to Materialism, but the eidos of such systems is what has to be understood in order to disclose Russian challenge to Enlightenment and its own tradition. The Russian writers comprise a point of crisis between two worlds, such that the crisis transcends both and is a critique from a transcendental position. But to understand these literatures it is necessary to offer a brief sketch of one level of Enlightenment.

\section{THE LIFEWORLD OF ENLIGHTENMENT}

The various major critiques of enlightenment, from Adorno through Heidegger, Habermas, Derrida, Levinas, to Deleuze fall within the parameters of one or another variant of Enlightenment, whether it is rationalism, psychologism, sociologism, economism, and even biologism. Valuations that are available, such as utilitarianism, deontologism, and voluntarism are equally variants of Enlightenment. Hence the task is to extricate the life world of Enlightenment from such variants at its very limit in order to reveal its eidos. The first is the well known dualism of subject and object, the former is mind, the latter is matter. The subject is the unconditional source of all theories and values while the material world is an irrational and valueless sum of homogeneous matter to be constructed in terms of the subject's theories and 
values. Second, the subject is unconditionally autonomous source of all laws in both the social and material realms. Since there is no other criterion concerning the material and social worlds, then all subjects are equal concerning the way that the material and social worlds are to be constructed. Third, construction is unconditional to the extent that no causes can be assigned to the structures and procedures by which the subject interprets and shapes itself, social relationships, and the material environment. In the language of Enlightenment, all are projections of human autonomy. Various terms have been used for projection: objectification, alienation, humanization, and even self-realization. It is important to note that the term "projection" is basic to political and scientific Enlightenments. Political Enlightenment posits the subject as an autonomous center of the public domain and all public rules and appointments of governing entities. Moreover, the public domain of autonomous subjects is strictly distinguished from the private-social domain of needs, wants, desires and their fulfillment. If the latter entered the public domain, it would abolish autonomy and equality. Sientific Enlightenment posits the subject as a rational bearer of theoretical and methodological constructs by which to manage the material environment in terms of projected human "needs". The latter are to be understood either biologically or psychologically and thus can be satisfied by scientific invention of "techniques" of fulfillment leading, to what is known, the reduction of scientific reason to instrumentality. Fourth, invention of history and its progress toward a utopian society; the latter assumed various interpretations, yet common to all is the notion that humans can construct a material and psychological setting wherein all previous ills would be abolished. It is obvious that this utopian notion, as "the aim and end of history" is a mixture of political and scientific Enlightenments. Fifth, the reason that this mixture had to be posited as a future aim is that political and scientific Enlightenments became incompatible; the scientific Enlightenment, and its promise to fulfill material and psychological wants, had to abolish the interpretation of human life as autonomous, unconditional and self creative.

The first requirement and interpretation of human life became material and psychological sum of wants and their immediate gratification. As we know, current reading of life and experience is regarded as a multiplicity of intensive pleasure nodes, each clamoring to be tickled, gratified, in order that new pleasure nodes could pop up for more gratification. Utilitarianism is the general 
ethical position wherein all things and humans have a value to the extent that they produce pleasure. Second requirement is the massive technology and its progress, designed for the constant fulfillment and constant invention of needs. The conjunction of these factors results in the abolition of historical aim and its replacement by progress for the sake of progress. This is obvious from the essence of instrumental rationality. Sixth, the notion of autonomy, the view of the subject as self creative had to be postponed and forever deferred, and also regarded as scientifically irrelevant and contradictory. It is impossible to claim that once the material and psychological conditions are fully established, then they will cause the human subject to be autonomous. As we know at the outset, autonomy cannot be caused. As just noted, this is equally problematic due to progress that can never reach any end and hence establish all the necessary conditions for emergence of autonomy. Every new condition, as a result of instrumental reason, becomes means for new conditions and new needs, and the latter split up into more novel needs. In this sense it is impossible to fulfill all human needs and then establish autonomy. Seventh, we are left with a democracy whose principle of human autonomy and the public domain wherein such autonomy is maintained and exercised is no longer available. It has been completely pervaded by instrumental rationality and the proliferation of needs and their fulfillment. Hence, the members of a political and democratic community are reduced to material life, psychological titillations, and chemical prolongation of boredom.

It is now possible to turn to the essence of the life world of Enlightenment: it is a process of valuation. Everything in the universe assumes a value to the extent that it serves our interests. Contrary to claims that the world has no value, the world constructed by Enlightenment, is full of values: labor theory of value (accepted and expounded by Radishchev), values for sale, values produced and to be produced, values of stocks and bonds, values of education, family values, religious values, ideologically constructed values, the changing and the new values, value of life and even calculated death, social values, and persons are judged as to their value in all of these settings. Indeed, the basic mode of awareness is valuative selectivity. It should be clear also that awareness and perception are no longer given in some pure empirical sense, but are selected on the grounds of valuation. In this sense, what is given as a plethora of empirical environment is, for the most part, ignored. What is 
perceived depends on its specific value. Indeed, there are social mechanisms that not only consist of values, but evaluation of values that select specific ones deemed relevant in terms of future value projects. It has been argued that all these values are human and hence the primacy is placed on modern subject as the source of values. This claim would hold if the human were a distinct and decisive category, wherein all other categories and processes were subservient to humans. But this is no longer the case, since other values, such as technologies of various sorts, from electronic media to genetic biochemistry compel the understanding of the human to be equivalent to the rest of the values. This means that genetic biochemistry will not treat the human as a special category, but will have to reduce all human functions to biochemistry. Thus the environment, that is constructed on the basis of the process of valuation and is deemed to be objective, requires that the human be treated equally objectively in terms of what such an environment demands, i.e., interpretation of the human as material, chemical, biological, physical entity in order that such constructed technical values could be applied and thus useful and valuable. Russian literature follows this trend as scientific modernization, expressed in writings of persons such as Turgenev, Chernichevski, Pisarov and others, where "objective" value constructs abound in the form of the new society.

We are now in a position to extricate the fundamental intentionality that constitutes this life world, that means it in a very specific way. To have some sense of this intentionality it is necessary to explicate the directly lived awareness that could not be posited as an object by the thinkers of enlightenment It ought to be understood that such a lived awareness is transcendental and hence accessible only reflectively from the meant objects that such a lived awareness intends. What then are these objects? While the process of valuation of events in favor of human "needs" was briefly indicated, i.e., various reductionisms of the human to biochemistry, genetics, and mechanics, the lived awareness subtending this process intends an objectivity which is unique to Enlightenment. One level of this objectivity is designed to be accessible to quantification and hence it has to be measurable homogeneous matter. This design, of course, is meant by a specific exclusion of the entire perceived world and hence in no wise accessible to experience. Yet covered by this homogeneous materiality as an intentional object is another intended 
objectivity: temporal possibility. Here again we encounter the major Russian writers, such as Herzen and just mentioned others, who advocate the total destruction of what has been a tradition and its replacement by not yet existing, possible, form of constructed society with the constant rejection of the possibility of capitalist economic system.

The live awareness that intends such an objectivity is an empty will, prior to the question of its being free or determined. Phenomenologically speaking, there can be eternal possibilities, as Plato and Husserl have noted, but such possibilities have been already enacted theologically and in part metaphysically. Enlightenment rejects eternal possibilities and is left with temporal, although in the first lived intentionality, empty temporal possibilities. It is to be noted that the term "temporal" does not suggest "being in time", but an open horizon without any specific ontological locus. Hence any temporal location would have to be established within such a horizon. If we attend to the language of Enlightenment up to date, we shall note that subtending the question of "reality" there is a prior discourse concerning the "conditions for the possibility of reality". Such discourses are premised on the first lived intentionality of empty temporal possibility. It opens a horizon of possible intentions and their fulfillment, requiring a second constitution of objectivities: possible valuations of what the will intends as valuable for us, but recalling that at this level all value possibilities are open as temporal. In principle, it is possible for us to be all that we will as valuable in time. This is Enlightenment's alpha and omega: empty temporal possibility and its temporal fulfillment by all that we value as our mode of final being. Both Marxism and capitalism offer the same intentionality. The intentionality of fulfillment of possible valuations as temporal does not lead to perceptual awareness, since the latter, in its immediate mode, is quite limited and merely qualitative. Hence the fulfillment requires a constructive intentionality that can establish possible conditions for possible reality. One minor aspect for this establishment is the shift of reason to instrumental rationality whose task is to calculate what reality is valuable for us and then calculate the conditions how such reality shall be achieved. Values, in this sense, are calculations of possible results realized solely as material. To achieve any value, the human has to be reduced to a system of interests, needs, desires, power and all must act aggressively against others to fulfill such wants. Indeed, language itself is split into numerous technical discourses. No doubt, the Russian 
Westernizers took this type of instrumental intentionality for granted, but also recognized that values signify a field of instrumental connections and are not ends in themselves.

The issue of temporal value possibilities is the driving force of Enlightenment at this level. Transcendent or eternal possibility is abolished; hence temporality is the pressure that demands a prolongation of our temporal existence. There is no other option; being temporal, we want to live as long as possible and hence the frantic rush for the latest technologies that promise to protract our lives. Such technologies have become equivalent to the value of life and death. The public domain is an arena for the struggle for life itself, and any means can be used, whether lying, killing, wars, all will do as well, as long as they promise to keep us safe, to insure our continuity at any price. All the changing technical inventions promote other inventions as values of life: we want to go on. The transcendental rule of enlightenment at this level is change as permanence enhancement. Thus the political shift to dramatic conservativism. The latter is a promise, by whatever means, to guarantee our security, safety, protection and continuity, as long as we surrender our freedoms to participate in the public domain and to engage in public dialogue. In other words, the public domain, as the condition for other democratic institutions, is no longer maintained, despite all the rhetoric about democracy and its "values". We are closer to Hobbesian world than to that of Locke and above all Kant. The intentionality of Enlightenment has worked itself out to reveal its truth two centuries later. Indeed, we are living this intentionality as an awareness of our life world in such a way that while speaking of democracy, rights, equality and freedoms, we intend such a world as a struggle for temporal and technical continuity. Thus all is valuable that enhances this continuity-and purely materially. The life world of Enlightenment that Russia encountered consisted of possible construction of iron, coal, cement, chemistry, biology and physiology. The human acquired a material value as producer, maker, a homo laborans, a man of science and ultimately a technocratic functionary in a system of conditions and results that became the Soviet model. 


\section{LIMITS OF ENLIGHTENMENT}

The interpretation of the world in terms of value did not escape Russian thinkers. Realizing the vast sweep of scientific reification of all spheres of life, including, according to Khomyakov, Hegelian idealism, Russia is in a position to offer spiritual values. While the latter may stem from theological understanding, they are primarily found, according to Kireyevsky, in the primacy of community of faithful whose tacit and intuitive awareness subtends the Western rationalistic abstractions. It is this constant reappearance of the background intuition that escapes value construction and demands-without becoming thematic-an evaluation of all values, whether they are rationalistic or materialistic. Indeed, there is a lived awareness that intends a given, although not directly articulated eidos expressed in terms of Russian superiority in morality and spirituality and offered as a salvation for the decadent, juridical, Bourgeoise, materialist West. As we shall see, this "superiority" is not offered only by Slavophiles, but also by modernizing Westernizers. Tacitly lived, this eidos is central to the Russian crisis and offers a transcendental awareness that is in a position of illuminating and questioning the legitimation of two possible life worlds. An immediate difference between values and the tacit intuition of this eidos is that the former are constructs, while the latter is regarded as given, although covered over by faulty social, political, metaphysical and even scientific preconceptions.

Resultantly, values and valuations have to be evaluated not by their own self proliferating construction, but by a discovery of a constitutive awareness that is correlated to a tacitly lived eidos offering the possibility of performing a suspension of commitment to a given life world. The transcendental requirement is to disclose this eidos that would be an all pervasive presence demanding either a transformation or rejection of a given life world. Instead of constructed values, this eidos can be called intrinsic self worth. As we shall see in Russian literatures such worth cannot be constructed and it appears in the background of all values and valuations. It also provides a background on which every life world can be regarded in its essential morphology and questioned concerning its legitimacy. This is to say that a given life world's limits are exhibited from a transcendental lived awareness that demands "more" and does so on the basis of discovery what this more is. The constitution of this more-intrinsic self worthis not a construction but a disclosure of an intentionality whose meant 
objectivity, its eidos as worth, is present as absolute. We should not despair while using the term absolute; after all, in all awareness there are such terms comprising a pregiven arche whose denial is its unavoidable inclusion. This is to say, to attempt to negate an arche is to include it in the very negation and hence to comprise its absolute affirmation. We shall call this the principle of self inclusion and venture a claim that only transcendental phenomenology is in a position to function within this principle. This is already intimated by the discovery of the more that plays a role in the evaluation of any life world such that any judgment relies totally on and includes this more. Russian literatures, which constantly appeal to this more as a demand for its fulfillment in concrete life, comprise a transcendental position of self inclusion. This is to say they offer a direct intuition into an eidos that is included in all evaluations of life worlds.

\section{THE CRISIS OF ENLIGHTENMENT'S LIFEWORLD}

Confronted with the inadequacy of feudalism and aristocratic rule and the emergent iron age, Russian writers, beginning with figures such as Turgieniev and Chernichievski, moving through Kineyevsky, Belinsky, Herzen, Bakunin, Lavrov, Mikhailovsky, Tolstoy and Dostoievski, Berdyaev, Shestov, Lossky, all the way to Gogol, had no choice but to place themselves between the two life worlds -the old and the new and thus to locate their writing as a point of crisis. The awareness of crises constitutes a unique reflective moment that, at the same time, allows a suspension of one's participation in a given life world. We are cognizant, by now, that while living in a particular life world we are not aware of its basic composition. We live in it as if it were self evident and all inclusive. There is nothing lacking in it to the extent that it would not offer relief and answers to all of our questions. If we claim to live in a democratic life world, we take for granted that our elected officials tend to lie, that we can vote them out of office, that the injustices can be corrected by legal means, and that those who work harder deserve more. We also know that we would not tolerate dictators or anyone who would deny our right to make our own choices and mistakes. There must be a unique situation which allows us to extricate from our life world and to raise the question of its legitimacy. That such a question can arise means that we rise to lived awareness which no longer belongs to a life world in which we live. 
This must be made clear: our awareness is always world oriented and our orientations, or intentional directions find, in their life world if not total, at least partial perceptual affirmation. This is an epistemic aspect which takes for granted the division of our life world into categories and the way they are concretized or given perceptual fulfillment. But the fulfillment of our taken for granted intentions and the categories to which they correlate, including the numerous value gradations-the epistemic understanding-leave out the legitimating question given in live awareness that something is not fulfilled, something that no value can account for: intrinsic self worth. To reach the latter, the lived awareness must suspend the life world and explicate the access to the transcendental lived awareness that correlates to intrinsic self worth and demands legitimation of the life world in which one has so far lived in full belief and affirmation. The lived awareness and its intention toward self worth asks whether the life world offers any fulfillment and confirmation of this intention. At this level of awareness the categorical and epistemic understanding fails, and an existential question of action becomes preeminent. Can I act, as I have always acted, and fulfill the intention of my intrinsic self worth? The latter embodies such requirements as honor, honesty, dignity, self and other respect, and justice. If honor, honesty, dignity and respect cannot be fulfilled in my activities, then the legitimacy of this life world is placed in absolute question, revealing at the same time the awareness of absolute self worth. It is at this juncture that the transcendental lived awareness in Russian literature recognizes that the world of values, constructed by Enlightenment and the world of decadent aristocracy require evaluation as to their adequacy for human worth. Such a question is one of principle that required an essential delimitation of the constructs of both worlds and whether they could be adjusted, discarded or become open to the absolute requirement of transcendental awareness of self worth. We are in a position, now to attempt our venture into lived awareness that is led by the intention correlated to self worth and thus place itself at the point of crisis.

While tradition demands respect for customary rules and social arrangements, (and Turgenev's Bozarov rightly asks from what such respect follows) but respect for them implies something more basic, some lived awareness that connects to the worth of a singular person beyond his/her value and demands a treatment of oneself and the others in an honorable, noble, 
truthful, elevating manner for its own sake. It is, then, the task to unfold the lived awareness that is compelled to bracket, to place out of action, the life world of tradition and Enlightenment and to note the presence of this lived awareness across diverse phenomena. All the intentional orientations toward a life world in which she has been immersed appear to be groundless constructs; the life world of public domain, which is no longer maintained, requires and recognizes a presence of intrinsic self worth even in its denial. In Turgenev's Fathers and Sons an epoche is performed raising the question of legitimation of the traditional Russian life world of aristocratic privilege in contrast to the value of the world of Enlightenment, and this very question places the questioner in a crisis situation. While we may think that this provides a comparison for choice, in lived awareness there appears an intention that connects to a question: which life world would provide actual fulfillment of the eidos of intrinsic worth. In the most degraded figures and the most elevated rebels there appears an intimation of self worth. Dostoievski gives back the key to paradise because the ruler of paradise values equally an innocent child and a decadent master. For the master, a favorite dog is more valuable than a child, and in the life world of feudal lords this is an acceptable standard. Dostoievski's rejection is an affirmation of human worth for its own sake. He will accept eternal damnation but will not accept a life world in which crimes against children are permitted. He raises an absolute question: is life worth living in a world where such a degradation of human worth is a standard, sanctioned and accepted even by the highest authority. Indeed, the entire corpus of Dostoievski's writings is a striving to disclose this awareness. In Brothers Karamazov, the main figure, Karamazov Dimitri, insults and degrades an impoverished elderly captain who no longer has any social value; yet toward the end of the story, Dimitri attempts to apologize by offering the captain money; impoverished as he is, the captain refuses to be bought and thus degraded again. He reveals his self worth as being above any price, above any social value, and "compels" Dimitri to recognize his own self worth in face of the other and his nobility, dignity and honor. In short, it is "illegitimate" to attempt to place a monitary value on self worth. Dimitri finally recognizes the self worth of the other and reflectively his own self worth, requiring honorable action and respect toward the other.

The question of legitimation of a life world may appear in a quiet and solitary figure, such as the one shown by Gogol. There is no doubt that the main 
character is depicted to comprise a search for self worth in face of a most bleak life world. It has been argued that this figure is driven by psychological desire for self importance or by a search for the appearance of a higher social status. Such desires may well be part of a personal morphology and a social situation, but they do not provide an adequate understanding of the intentionality involved in these drives or desires. Subtending and covered over both by psychologically and socially constructed phenomena appears an almost quixotic quest to reach something psychologically and socially unreachable and yet totally present in his lived awareness: I am worthy, I have dignity, self and other respect, and honor. The point is that such an awareness is not within the realm of prevalent social values or psychological feelings, since his social value will in no wise change with the acquisition of the Great Coat. He will remain in his meager occupation, still hungry and without candle light at night, without any hope for a better tomorrow. In brief, he will not get any value out of his struggling and striving apart from the recognition of his intrinsic worth for its own sake. Across Russian literature appears something given to awareness that is akin to Kant's thing in itself that possesses no purpose and no value, but is to be respected unconditionally. While Enlightenment opened up an entire level of constructs called values and announced that the thing in itself is unknowable, Russian literature is intent in showing that any question of legitimation of a given life world discloses a transcendental constitution of self worth as the thing in itself.

Let us look at the logic of intrinsic worth. In the life world where everything is a trash bin of values, there emerge personal actions and expressions that demand honor, dignity, respect, truthfulness, not only of themselves but of others. Indeed, their actions are equally an indication of intrinsic self worth of others. The intentionality of consciousness as teleological is accepted both by the "rationalistic" Westernizers, from Belinsky through Herzen wherein consciousness is irreducible to scientific explanations, and the writers who emphasize Russian spirituality. This intentionality aims at its telos which is the point of critique of Russian and Western life worlds. Yet both reject the materialistic-rationalistic West as decadent, purposless and even nihilistic despite its technical sophistication and extol the Russian man as a model of salvation. This model is distinguished from Western and Asiatic types by its striving, despite the Russian cultural veneer, to exhibit dignity, honor, truthfulness in action. Thus, Mikhailovsky makes a distinction between types 
and levels of civilization. West may have a higher level of material civilization but Russia is a superior type due to its intuitive understanding of the personal dignity and intrinsic self worth of an individual. Even Herzen and Bakunin, while living as exiles, extolled the superiority of the Russian type of awareness of this dignity. Indeed, all the social degradations imposed by serfdom as a traditional value gradation reveal the common Russian acceptance of the absolute worth of a person. After all, it would be impossible to degrade others without recognizing the other as a possessor of intrinsic self worth. We cannot degrade a creature who, in its life world, does not recognize a need to justify its deeds, to make a choice between two life worlds; in short, to call a dog-dog, is neither a degradation nor a negation of intrinsic worth. Only another person can be degraded on the basis of recognition of her intrinsic worth. This is to say, degradation, reduction, insult, are possible only when we recognize hers and our own intrinsic worth, honor, and dignity.

Degrading of others in an effort to elevate oneself, is an indication of the worth of others, an indication of our anxiety in face of the other's intrinsic self worth, her unavoidable height. Unable to withstand the other's self worth, we condemn her to death and thus prove that we are unwilling to admit our own self degradation, our own crisis, and cannot withstand the dignity of the intrinsic self worth of another. The outcasts, the exiles to Siberia who have lost all social value still strive to exhibit dignity, honor, respect and thus reveal the final human position for its own sake that cannot be abolished even when threatened by death. This is the Russian positive negativity: Even at the pain of death I shall say no to a life world that does not allow my self worth to be fulfilled. This merely discloses the constitution of self worth as transcendental given that is beyond life and death. This appears in extreme cases where the guards who manage prisons immediately condemn to death anyone who shows self and other respect, dignity and honor. Here is a recognition and a lack of honor and dignity in the guards who function as valuable servants of the state. This logic calls to the others to recognize the crisis in their lives, to legitimate the life world in which they live and to ask whether such a life world fulfills their lived awareness of their intrinsic worth. This is to say, the very presence of the other who is aware of her intrinsic worth performs a tacit phenomenological bracketing and hence challenges a blind inherence in this life world. One can then raise a question whether such a life world is worthy of one's intrinsic worth. 
We reached a juncture at which the founder of Western philosophySocrates-can make his entrance. Although scholars locate Socrates as the relentless seeker of truth, i.e., categorical epistemologist, we must also recall that the first condition of the search for truth is the good and a life world where a person can live in accordance with the demands of the good as one expression of intrinsic worth. Only under these conditions that Socrates can search for truth as another aspect of intrinsic worth. After all, the search for truth was, for Socrates, a practical-existential commitment and activity of a good and truthful life. Thus Socrates, like many others, was an object of derision and caricatures. He accepted the Athenian verdict of death in order to show that his and others intrinsic worth demands a life world in which the search for truth cannot be forbidden. He placed his internal worth as the good above his personal life and could demand that such a good should be a part of his life world. The decision by the jury to forbid Socrates his daimon, his eros, to "philosophize" was equivalent to a destruction of a life world in which his intrinsic worth once had a place. Socrates is compelled to face a crisis and reveal a crisis of his life world. He reaches and lives an awareness that places his entire life world into question and demands a decision: Is the life world, offered by Athenians, adequate to fulfill his intrinsic self worth. In turn, have the Athenians, by their own action, degraded themselves to a level of social value where truth, dignity, honor, will have no place. After all, such a degradation to social value is obvious from the trial when Socrates is offered a chance to surrender his troublesome quest and thus become a valuable citizen, and when Socrates offers, ironically, to accept a pension from the state for "whatever little services that he might render". Here appears a depiction of the first crisis of democracy and Socrates reaches a lived awareness which demands a legitimation of the life world which is being offered to him. Can his lived awareness, correlated as it is to intrinsic self worth, have any perceptual affirmation in such a life world? The latter, after all, demands self degradation and thus the denial of self worth. Socrates resolves the crisis by accepting the verdict of the Athenians with a warning: If you condemn me, my fame will spread far and wide; do not do this, because it will be forever a black mark on Athens.

But what do we get at the other end of Socratic tradition where the lived awareness of intrinsic self worth seems to be destroyed in the pronouncements of Nihilism that appeared amidst Russian intellectuals and writers. Perhaps the 
most extreme pronouncements came from persons such as Herzen and even from writers toying with the death of god theme. After all, Dostoievski proposes a thesis that if god is dead, then everything is permitted. As we know Herzen not only challenges the continuous life world of values, but attempts to devalue all values, to discard all meaning, aim and purpose, to burn down all that has been achieved and to set human life adrift on a turbulent ocean in a ship without a rudder. What is left over is blind, irrational, clashing powers, arbitrary decisions and complete self degradation of the human into materialism. Yet the same Herzen strives to find an answer to a question: given the meaningless, devalued, directionless and purposeless universe, how shall we live? He opens the lived awareness that intends self worth as self creation. It is significant that such self creation is precisely what is required of self worth: its own purpose, having no value for anyone, and above all for social functioning-it creates itself for its own sake. The metaphor of life is no longer "all for nothing" but self creation as its own worth. In this sense nihilism and the devaluation of all values does not abolish philosophical quest for self worth; to the contrary, it clears away all obfuscations and offers a higher opening to transcendental self awareness. After all, it elevates awareness to encompass the cosmos as meaningless, and asks the ultimate question whether this cosmos is open for self worth. And the answer is absolutely yes, and precisely because the constructed and purposeful values have obfuscated the most fundamental human awareness: first and foremost, I must demand of myself and others to be self creators following directly in purposeless recognition of absolute self worth for its own sake.

What the Russian writers have in common with Socrates is that, just as he, they were not professional philosophers but persons who demanded the recognition not only of their own, but of everyone's unconditional self worth. And just as Socrates, all of them (with an exception of Tolstoy who, nevertheless, was excommunicated) placed self worth above their own safety, wealth, security, social position and were exiled, imprisoned, persecuted, and censored. They placed self worth above their life and dared to say no to their own and that of Enlightenment's life worlds. In this sense the claims that various Russian writers, inclusive of Chernichevsky, Turgenev, and even Dostoievski were nihilists are wrong. Nihilism rejects the world of values and meaning without offering anything positive in their place. Not so with the Russian writers 
whose transcendental awareness of self worth is the only viable position from which life worlds can be illuminated in essence and disclosed as to what kind of activity cannot be fulfilled. No doubt, they toyed with democracy and equality of all persons, but they also realized from their experience in the West that democracy was in crisis. West in general has abolished the public domain, where autonomous citizens could rationally debate public issues, by reducing it to the clashing sum of private interests and power confrontations. The rationality of Western man, as Dostoievski noted, is a facade under which there lurk all sorts of irrational drives, such as greed, envy, aggression and incivility. Hence, the notion of freedom and above all self worth can no longer be offered by the West. Now the previous principle of self inclusion can be concretized. A person, who recognizes absolute self worth, as do the Russian writers, does not propose it as a thesis but a demand in action that includes the very person who lives the awareness of self worth. Hence, despite their loss of social value positions, of wealth, of freedom to write, they subsumed themselves under this absolute awareness and acted accordingly.

\section{ESSENTIAL AWARENESS}

The point has been reached where a question of awareness of self worth can be answered. First aspect of this awareness is the possibility to extricate oneself from a specific life world. Second, the resultant disattachment, or bracketing of this immersion is the awareness of self worth demanding the possibility of world orientation that would answer the question of absolute legitimation of fulfilling in practice and action what the awareness always tacitly maintained as self worth. Third, it is to be noted that such awareness transgresses any specific life world, since any life world may offer partialperceptual or signitive fulfillment of intrinsic self worth. Under any other circumstance, intrinsic worth would be an intentionality of a given life world, interpreted, for example as value, equivalent to other values, and hence a self understood part of such a world whose refusal would go counter to what is categorically self evident in such a world. At this level a refusal to participate in such a world would be impossible. In other words, intrinsic worth is not a perceptual given, but arises "perspectively" to the extent that we can regard our lived world as total from the perspective of intrinsic worth. This perspectivity 
is the price for our freedom to survey any life world and ask the question of legitimation. In this context, the persons who were mentioned, whether Turgenev or Gogol, or even Socrates, articulate phenomena that disclose intrinsic worth and demand of us to recognize our degraded state. As already stated, the recognition of other's intrinsic worth is equivalent to the recognition of our own and conversely.

The awareness, correlated to intrinsic self worth, is a transcendental background on which any life world must be legitimated concerning its adequacy for fulfilling such awareness in activity. It was noted that the life world of enlightenment at its epitomy, offered us a world of values which had no other source except unlimited construction and hence unbound from any restriction concerning the manner in which such values are used. This leads to arbitrariness and power to the extent that power must decide which values are victorious for a while. But the transcendental background of intrinsic self worth was and is equally a given and provides a limit concerning the unrestricted valuations. The founders of Enlightenment and its correlate-political democracy-were persons who extolled honor, dignity, respect, truthfulness and justice in their actions and demanded no less of their adversaries. This comprises the background on which the crises of democracy appears. At the founding just as well as now, there appears a first transcendental rule of awareness: maintenance of permanent self worth and currently its reclaiming. This rule, then demands an establishment of a first democratic institution-public domain-in which every person must fulfill her self worth, for its own sake. This very fulfillment demands, in turn, the second rule of awareness: permanent maintenance of the public domain for its own sake. Such maintenance requires the bracketing, exclusion, of arbitrary constructed valuations-such as economic, power, religious, ethnic, racist, that would promote the abolition of the public domain and self worth; indeed, such valuations do produce rhetorical means to obfuscate their degrading and disruptive tactics. Such oxymorons as "free enterprise", "public leadership" and even "free expression" comprise some of the rhetorical means. This sort of engagement comprises a third rule: valuations as disruption of the permanence of self worth. This rule is quite prevalent and has been at the background of such events as public apathy, non-participation in public affairs, and pervasive anti-intellectualism and anti-education. When the public arena is filled with all sorts of private interests, needs, desires, cultic dogmas that are at 
odds with each other, then either we also push for our interests or, lacking knowledge of such interests, we decline to participate. It must be emphasized that self worth and the public domain are not objects of knowledge but are constituted in our active engagement. If we cease to act honorably, justly, nobly, respectfully, we shall not have self worth or public domain wherein self worth is enacted. It must be also noted that freedom as autonomy is a result of self worth; after all, we extricate ourselves from our own and other life worlds and demand legitimation as to their adequacy for self worth. Only on this ground can we select a life world that permits autonomy for its own sake. But autonomy, at this level, is valid only if it is correlated and subject to self worth. Without the latter, autonomy may become reduced to "free choice" among things and lose its legislative dignity.

It seems that the initial or founding intentionality of Enlightenment has permitted a partial fulfillment of self worth in the awareness of autonomy, yet the interpretation of the latter became restricted to the understanding of its period which mixed scientific explanations with freedom of research, rights to self invention and subject to no one. Scientific explanations were extolled as the sole avenue to truth, and offered categorical divisions of all things, while humanities, wanting to be scientific, engaged in equal categorization of its own disciplines, from theologies and their classification, to literatures. Categorization also subjected the human activity to become substantivated into categorizable characteristics: so and so is valuable, a business person, a teacher, etc., thus excluding the quest to return to activities that could be the sole understanding of what such categories mean. As we know, suddenly such categories, defining a person, could be acquired by numerous means, including money. Self worth, as an enactment, a participatory engagement vanished behind epistemic terms. We are all citizens, with characteristics such as rights, freedoms, and even entitlements, but if citizen is only the one who actively maintains the public domain as a space of self worth, then how can one speak of inhabitants who refuse to participate in public's life world? This is the point of crisis, requiring of all inhabitants of a society to become citizens.

It is self worth that discloses the partial fulfillment by enlightenment and hence demands more from the inhabitant, not as a Kantian duty in face of a law, but as a demand of self respect and respect of others. After all, even "professional" philosopher such as Berdyaev parted both with Marxists who 
completely disregarded concrete persons, and with Kant because beyond duty there is worth and dignity of a person. For Berdyaev Marxist ethics were different for each social-historical period without providing a criterion by which to judge their worth. Resultantly, there must be an absolute standard, an eidos as intrinsic self worth of a person. Once the trust in a life world turns to mistrust and is placed into doubt, then the already stated issue of legitimation comes to the fore. It is possible to state that the legitimation crisis, suggested by Habermas, has located the crisis at the level of value of multiple interests, demanding a public arena where such interests could be articulated, in competent speech, equivalently by any group. Yet the crisis, as was contended above, must be sought at the primary level of awareness of self worth, and not at the level of participatory interests. What is more important is that the question of legitimation of a life world leads not only to activity, but to the transcendental awareness of singular commitment, to a question of existence and not knowledge. The appearance of partial life world, i.e., incapable of supporting self worth, gives rise to a fragile resistance with the question of the individual's existence in such a world, search to fulfill the more in awareness than the world offers. The "more" is a striving to disclose whether I myself am more than this life world and whether I have a choice and worth to live otherwise. To understand this shift toward requirements of active existence we need to specify more precisely the transformation from epistemic understanding that depends on second and third grammatical persons, to a first person's self understanding and the recognition that the latter is not a narrowing down of the epistemic categorical field but has a very different logic. For example, if categorical language has truth in perceptual fulfillment of a proposition, existential proposition has truth as an honorable act of not lying. Categorical language is designed to open some general characteristics, while existential is singular and unique, and even nonrepeatable. This kind of requirement is what led Sartre to existentialism as a humanism, Nietzsche's Third and Fourth books of Zarathustra, and to Taoism's discovery of total, singular authenticity. Even Heidegger attempted to articulate such an authenticity, but failed by giving priority to historical hermeneutics that contextualized authenticity within the parameters of early Greek and contemporary German languages.

What was given in Enlightenment as a background awareness, is now in the foreground of the life world of Enlightenment and the unfolding of the 
constructive-valuative intentionality that has become prevalent. Being in the foreground or "positional" and thematized this awareness points to the problem of legitimation and to the illegitimate ways that the basic awareness became obfuscated, degraded, perverted, brutal and violent. Tolstoy's testament of peace, of no participation in state's activities that are demeaning of anyone impacted Gandhi to challenge without violence an entire life world of an empire. It questions the claim of this life world to be the only legitimate reality. This claim to sole reality appears only when the self worth becomes a foreground, enacted by a singular being in quest for an authentic fulfillment of self worth in a life world that at one stroke is made inactive, placed out of play. On the background of the life world that is placed out of play in its totality there appears a quest to act in favor of a world that would contain self worth. The life world without human worth is exposed to temporality: it becomes chronoscopic, i.e., an inadequate temporal perspective on the reality of the essence of the human. Such temporalization suggests that there is an atemporal, non-positional awareness which, inevitably can appear only chronoscopically. It is equally important to note that since the disclosure of self worth revealed it to be solely as activity and not accessible through categorical intuition, then honor, dignity, nobility, truthfulness and justice appear only as enacted phenomena and hence have validity to the extent of their enactment. In addition, the striving to enact intrinsic worth is also a chronoscopic awareness, since no single activity, whether honorable, noble or truthful, fulfill the entirety of the search for self worth. As an activity for its own sake, self worth also demands, as already suggested, public domain wherein such activity can be performed, resulting in the notion that such a domain is to be maintained for its own sake. Both, self worth and public domain are phenomena that mutually require one another and hence are to be maintained as purposes in themselves.

Yet even the awareness of such purposes in themselves requires one more domain of awareness. The disclosure of intrinsic worth as atemporally present, but only chronoscopically experienced, requires a specific constitution of activity. As we know, awareness is oriented toward the world. Yet such orientation is experienced reflectively, such that the world becomes represented and the self becomes represented as awareness that is turned toward the world. In view of her orientation as intentional aim, she also finds confronted by herself. Such orientation toward the world in face of oneself is the essence of 
activity. Given the awareness of such activity, the latter places another demand: not only reflection that represents an aim toward the world and the one who intends such an aim, but above all asks for legitimation as to the worth of such an action. At this level one does not ask whether such a world is known -this is already granted, but is this world worthy of one's activity. The possibility of constituting a worthy life world is the reflective condition from which the failures of our degraded life world become visible.

\section{POSTSCRIPT}

The Russian writers, mentioned in this essay, are almost pure embodiments of intrinsic worth. But we also know that such figures are targets of attack at every turn in their lives. In the daily life of commerce with commodities, religions, family values, political cunning, and rhetorical obfuscations, such figures seem not to have any value. Imagine a business person in a position to make a solid profit in a shady-although legal way-would refuse to do so in order to act in an honorable manner? He would be an object of jokes, indeed a figure of no social value. But this also means that he has not yet reached a reflective awareness at which his intrinsic self worth is disclosed. At the same time, such a person has no ground for living in a democratic society, and resultantly cannot be an autonomous being in a free public domain. We must recall, nonetheless, that self worth was constantly in the background of the continuous founding of democracy. Those who understood that democracy is not an entity but a constant founding activity, also regarded their honor, dignity, nobility of spirit to be sacred. 